\title{
Trading privileges for support: the strategic co-optation of emerging powers into international institutions
}

\author{
Andreas Kruck* (iD) and Bernhard Zangl \\ Ludwig-Maximilians-University Munich, Institute for Political Science, Oettingenstr. 67, 80538 Munich, \\ Germany \\ ${ }^{\star}$ Corresponding author. Email: Andreas.Kruck@gsi.uni-muenchen.de
}

(Received 15 September 2017; revised 14 March 2019; accepted 1 July 2019)

\begin{abstract}
As emerging powers rise and established powers decline, international institutions come under pressure to adjust to new power realities. When and how do international institutions adapt to underlying global power shifts? We propose an (institutionalist) theory of strategic co-optation that differs from both (realist) accommodationist and (liberal) integrationist theories. Drawing on isolated treatments of strategic co-optation from other domains - domestic and international, autocratic and democratic, past and present we develop a theory of strategic co-optation as a mode of institutional adaption to shifts in the global distribution of power. The theory specifies the concept, the conditions and the (unintended) consequences of strategic co-optation. We conceptualize co-optation as a specific form of adaptation where established powers trade institutional privileges for emerging powers' institutional support. We theorize the conditions under which emerging and established powers are (more or less) likely to strike a co-optation deal. In addition, we identify endogenous dynamics that may render co-optation precarious and thus subject to instabilities. While the ambition of this paper is primarily theoretical, we provide various empirical illustrations of how strategic co-optation is used to adapt international institutions to contemporary shifts in the global distribution of power.
\end{abstract}

Keywords: power shift; power transition; institutional change; co-optation; international institutions; global order

\section{Contending approaches to global power shifts}

As emerging powers such as China and India rise and established powers such as the USA and the UK decline, international institutions such as the United Nations (UN), the World Trade Organization (WTO), the International Monetary Fund (IMF), and the World Bank (WB) come under pressure to adapt to shifts in the global distribution of power. When and how do they adapt?

(C) Cambridge University Press, 2019. This is an Open Access article, distributed under the terms of the Creative Commons Attribution licence (http://creativecommons.org/licenses/by/4.0/), which permits unrestricted re-use, distribution, and reproduction in any medium, provided the original work is properly cited. 
Earlier power transition theories (PTTs) discussed whether peaceful institutional adaptations to power transitions, in which a rising challenger replaces a declining hegemon, were actually possible (Organski 1968; Organski and Kugler 1980; Gilpin 1981; Modelski 1987, 2005; Layne 1993). More recent power shift theories (PSTs) have given up the traditional PTT focus on full-blown power transitions to study institutional adaptations to global power shifts instead (Schweller and $\mathrm{Pu}$ 2011; Stephen 2012; Kahler 2013; Paul 2016). Power shifts imply that emerging powers overtake some of the established powers, but, in contrast to full-blown power transitions, are not (yet) able to challenge the incumbent hegemon. Many recent PST contributions have likewise moved their focus from studying shifts in the overall power structure towards issue-area-specific power shifts (Schirm 2010; Wade 2011; Hopewell 2015; Zangl et al. 2016). ${ }^{1}$ Instead of analyzing the global order as a whole, they study the adaptation of specific institutions to issue-area-specific global power shifts (Stephen 2012; Lipscy 2017; Daßler, Kruck and Zangl 2018). Moreover, recent PST contributions challenge the gloomy assumption of earlier PTTs that institutional adaptations are rarely possible and major warfare is inevitable (Ikenberry 2009, 2011a, b; Kirshner 2012; Kahler 2013; Paul 2016).

Even PST contributions that draw on realist theories of International Relations (IR) argue that established powers may accommodate emerging powers' demands for institutional adjustments that reflect their improved power position (Kirshner 2012; Paul 2016). To be sure, the accommodationist approach highlights that power shifts will exacerbate conflicts of interest between established and emerging powers entailing the risk of war. It is, however, precisely this risk that can provide an incentive for established powers to proactively manage the rise of emerging powers by accommodating them through institutional adjustments. After all, these institutional adjustments may prevent the need for a fundamental institutional overhaul in the future when the distribution of power shifts further in favor of the emerging powers.

Many PST contributions that draw on liberal traditions in IR argue, by contrast, that emerging powers will seek their integration into the current order and its institutions rather than asking for far-reaching institutional adjustments. These integrationist approaches assume that the current global order is easier to join and more difficult to overthrow than previous orders (Ikenberry and Wright 2008; Ikenberry 2009, 2011a, b; Kahler 2013). As it was the current order that allowed them to rise, emerging powers are more interested in sustaining it and its institutions than in overthrowing them. Moreover, through their previous integration into the order and its institutions, emerging powers have gone through a process of socialization and have already internalized the order's most fundamental principles. This allows for their fairly harmonious further integration into the order and its institutions.

\footnotetext{
${ }^{1}$ Accordingly, we identify established and emerging powers based on their issue-area-specific (relative) material capabilities (Brooks and Wohlforth 2015/2016). In many issue areas, we consider states such as the USA, the UK, France, and Germany as established powers because, in terms of their issue-area-specific power resources (such as GDP with regard to trade), they have been the most powerful states over several decades. By contrast, states such as China, India, and Brazil are in many issue areas emerging powers because, in terms of issue-area-specific power resources, they have been able to overtake some of the established powers within the last two decades.
} 
From our point of view, both accommodationist and integrationist approaches identify important modes of institutional adjustment to the shifts in the global distribution of power. However, insofar as they focus on either conflictual accommodation or harmonious integration, they overlook a third mode of institutional adaptation that we call strategic co-optation. To some extent, co-optation is a combination of accommodation and integration, and we find occasional references to 'co-optation' in both accommodationist and integrationist PST contributions (Stephen 2012, 296-298; Acharya 2014, 154; Paul 2016, 18; Newman and Zala $2018,871)$. However, co-optation differs from both accommodation and integration in important ways. Accommodation means that established powers adjust (unilaterally) to emerging powers' demands for institutional adaptation; integration, on the other hand, means that emerging powers adjust (unilaterally) to the existing institutions. Co-optation, by contrast, is a specific form of mutual adjustment. It implies that established and emerging powers trade institutional privileges (as in accommodation) for institutional support (as in integration). For example, in the wake of the global financial crisis (2008), China provided crucial financial support to contain the crisis and thus stabilize the IMF in exchange for increased voting rights in the IMF (Wade 2011; Keukeleire and Hooijmaaijers 2014).

The aim of this paper is to develop a theory of strategic co-optation and to illustrate its empirical relevance with regard to the adaptation of international institutions to global power shifts. ${ }^{2}$ Drawing on isolated treatments from various domains - domestic (cf. Selznick 1964; Hale 2015) and international (cf. Lake 2009; Abbott et al. 2019), autocratic (cf. Dickson 2000, 2008; Reuter and Robertson 2015) and democratic (cf. Lehmbruch 1984, 1987), past (cf. Trotha 1994; Wilson 2016) and present (cf. Gandhi and Przeworski 2006, Geddes et al. 2018) - we develop a theory that specifies, for the specific context of institutional adaptation to shifts in the global distribution of power, the concept, the conditions, and the (unintended) consequences of strategic co-optation. We first conceptualize co-optation as a specific form of mutual adjustment - or cooperation - in which established and emerging powers trade institutional privileges for institutional support. We go on to theorize the conditions under which, in the face of a global power shift, emerging and established powers are (more or less) likely to agree on a deal of this kind. We then discuss endogenous dynamics that can stabilize co-optation, but also destabilize it rendering it precarious. In the conclusion we summarize and suggest that our theory may also improve understanding of strategic co-optation beyond the context of institutional adaptations to global power shifts (i.e. beyond this scope condition).

\footnotetext{
${ }^{2}$ Drawing on Krasner (1983) and Keohane (1989), we define international institutions as sets of international rules, norms and principles - be they substantive or procedural, formal, or informal - around which actors' expectations of appropriate behavior converge. International institutions include international organizations such as the WTO, international regimes such as the nuclear non-proliferation regime and international networks such as the G7.
} 


\section{Conceptualizing strategic co-optation}

Generally, co-optation entails that individual or collective actors are brought closer to the leadership of an institution. It is a specific process of institutional adjustment where either the exercise or the burden of power, or both, are increasingly shared between existing power holders and other power centers to stabilize an institution (Selznick 1964; Dickson 2000; Gandhi and Przeworski 2006). Examples of co-optation from the domestic realm include the co-optation of labor unions (Lehmbruch 1984), churches (Abdullah 2015), or ethnic minorities (Pettai and Hallik 2002) into the institutions of democratic states, as well as the co-optation of opposition parties (Gandhi and Przeworski 2006), regional leaders (Reuter and Robertson 2015), private entrepreneurs (Dickson 2000, 2008; Gerschewski 2019), elite networks (Hale 2015), or rebel groups (Thomas, Kiser and Casebeer 2005, 124-125; Salehyan 2019) into the institutions of autocratic regimes (Wintrobe 1998; Geddes et al. 2018). Examples from the international realm include the co-optation of local chiefs into colonial empires (Crowder 1964; Trotha 1994, 261) or of client states into hegemonic orders (Lake 2009).

We focus on strategic co-optation, which we conceptualize as the result of strategic choices made by the co-optor and the co-optee. Independent of the specific context, their fundamental co-optation bargain is always the same: they trade institutional privileges for institutional support to stabilize the institutional order (Selznick 1964, 135-136). When democratic leaders engage in co-optation, they provide, in exchange for support, tax exemptions to churches, privileged representation for ethnic minorities or consultation rights for unions (Lehmbruch 1987). When autocratic leaders engage in co-optation, then, in return for support, they give opposition parties seats in parliament, include economic elites in their governing coalitions and provide ministerial posts for rebel leaders (Dickson 2000; Gandhi and Przeworski 2006; Reuter and Robertson 2015). When colonial states co-opted local chiefs, they gave them institutional privileges and opportunities for rent-seeking in return for their support (Trotha 1994). Hegemonic powers that co-opt client states typically give them security guarantees in return for their loyalty (Lake 2009). In each of these cases, the co-optor grants institutional privileges that give co-optees a stake in stabilizing the existing order (Baur and Schmitz 2012, 11; Gerschewski 2013, 22).

As these examples indicate, strategic co-optation requires cooperation. The co-optor grants privileges and the co-optee gives support in return. However, strategic co-optation is a very specific form of cooperation - and not only because the co-optor and co-optee trade institutional privileges for institutional support, but also because it is not a form of horizontal cooperation among equals, but rather of vertical cooperation among unequal actors with the co-optor having more authority than the co-optee (Selznick 1964; Dickson 2000; Gandhi and Przeworski 2006). Ex ante, co-optors dominate the order and its underlying institutions. They are in a leadership position. They have institutional privileges and thus authority that co-optees lack. Ex post, co-optation reduces the status hierarchy between co-optor and co-optee. Through the granting of institutional privileges, co-optation typically gives co-optees more authority and brings them closer to the leadership of the order and its institutions. Yet, co-optees usually do not become equal co-leaders. In return for support, they gain privileges, but they do not gain the same privileges 
- and thus the same authority - as the co-optors. When autocratic governments co-opt leaders of the opposition by giving them seats in parliament (Gandhi and Przeworski 2006) or democratic governments co-opt the leaders of the labor unions or employer associations by incorporating them into their policy making (Lehmbruch 1987), they still keep them subordinated. Co-optation preserves some status hierarchy (Dickson 2000; Bertocchi and Spagat 2001; Hale 2015).

While co-optation always entails the same vertical cooperation among unequal actors that exchange institutional privileges for institutional support, the privileges granted and the support provided may vary substantially:

- First, whether formal or informal, the institutional privileges gained by the co-optee will be either procedural or substantive. Procedural privileges entail co-optees gaining more influence in the policy-making process (Lehmbruch 1987). The 2002 opening of the Chinese Communist Party to private entrepreneurs in return for their support of the communist regime may serve as an example. In becoming party members, private entrepreneurs not only enhanced their social status, they also improved their ability to make their economic interests heard (Dickson 2008). Privileges can, however, also be substantive (Reuter and Robertson 2015). In return for their support in the run-up to the 1996 presidential elections, President Yeltsin offered the managers of big Russian oil and gas companies the opportunity to become the owners of those companies (Shleifer and Treisman 2005).

- Second, whether ideational or material, the support co-optees provide to stabilize the existing order can be either specific or diffuse (Easton 1975). Co-opting specific support entails the co-opted party fulfilling a specific task in exchange for the institutional privileges granted by the co-optor. The co-optation of the Russian oligarchs who supported President Yeltsin's 1996 electoral campaign in return for becoming the owners of the gas and oil companies they managed provides an example (Shleifer and Treismann 2005). Co-opting diffuse support implies, by contrast, that in return for the privileges granted, the co-optee is expected to be generally loyal to the order and its underlying institutions (Hale 2015; Geddes et al. 2018). The communist leadership in China did not open up the party with the objective of private entrepreneurs fulfilling a specific task. Instead, private entrepreneurs were encouraged to get party membership to give them a stake in maintaining the order and thus to generally enhance their support for the communist regime (Dickson 2008).

Importantly, strategic co-optation - understood as vertical cooperation among unequal actors that exchange institutional privileges for institutional support - is also common when international institutions adjust to shifts in the global distribution of power. Established powers co-opt emerging powers to stabilize international institutions and the order they underpin. For example, in the aftermath of the 2008 global financial crisis, the USA and the other G7 states offered emerging powers such as Brazil, India, and China (the BICs) an institutional upgrade of the G20 from being a forum of finance ministers to being a forum of heads of government. Through this partial replacement of the G7, they granted emerging economies the 
privilege of membership in the exclusive club of leading economic powers that govern the global political economy. They did so in return for the BICs' institutional support. The latter pledged financial resources to help contain the financial crisis and endorsed the G20 as a crucial global economic governance forum. In the end, the upgrade of the G20 brought the BICs closer to the core leadership of global economic governance, but, as the G7 continues to exist, its members retain a privileged position in the G20 (Wade 2011; Cooper and Thakur 2013; Kirton 2013).

The co-optation of the BICs into the G20 is not, in fact, an exceptional case of co-optation in the wake of shifts in the global distribution of power. As we will indicate below, China's integration into the WTO, India's unofficial recognition as a nuclear power, China's increased voting rights in the IMF, Germany, Japan, India, and Brazil's (i.e. the G4's) attempt to gain permanent seats in the United Nations Security Council (UNSC), and China's inclusion in the WTO core negotiation group provide additional examples.

\section{Conditions for strategic co-optation}

While we consider co-optation an important means of adjusting international institutions to global power shifts, we also highlight the fact that emerging and established powers are not always able to agree on it (Stephen 2012). What, therefore, are the conditions for co-optation and thus the exchange of institutional privileges for support? To answer this question, we draw again on the treatments of co-optation cited above from other domains.

While often more implicit than explicit, the most fundamental assumption of most co-optation accounts is that co-optation is only possible if the benefits outweigh the costs for both co-optor and co-optee (Bertocchi and Spagat 2001). For the co-optor, the gains from the co-optee's support of the order must outweigh the relative loss implied by granting institutional privileges to the co-optee. For the co-optee, the benefits of additional institutional privileges must outweigh the costs of supporting the order. But what shapes the cost-benefit assessment of co-optors and co-optees? In the following, we elaborate on three conditions. We begin by conceptualizing the existence of a fundamental institutional challenge as a necessary condition for strategic co-optation. We then discuss two probability drivers of strategic co-optation: the availability of willing and able co-optees on the one hand, and the institutional opportunities for the co-optation parties to overcome resistance from interested third parties on the other.

\section{Fundamental challenge as a necessary condition}

Many co-optation accounts regard a fundamental challenge to the order and its institutions as an important condition for strategic co-optation - some even consider it a defining feature (Selznick 1964; Dickson 2000; Gandhi and Przeworski 2006). Following these accounts, we regard a fundamental challenge to the existing order and its institutions a necessary condition for strategic co-optation.

However, different accounts of co-optation focus on different challenges. By fusing these isolated accounts into one theory of strategic co-optation, we highlight two key distinctions: 
(1) Authority vs. governance challenge: Co-optors may draw on co-optation to cope with challenges to their authority. This is the focus of the literature on co-optation in modern autocracies (Wintrobe 1998; Dickson 2000; Gerschewski 2013, 2019; Hale 2015; Geddes et al. 2018). It shows, for instance, that autocratic regimes use parliamentary assemblies to tame the opposition to their authority by giving opposition leaders the institutional privilege of parliamentary membership (Gandhi and Przeworski 2006). This gives those leaders a stake in the maintenance of the existing order and strengthens the diffuse support for it (Dickson 2008). Here, strategic co-optation is a technique used to maintain authority.

However, co-optors may also draw on co-optation to deal with challenges to their governance capacity. This is the focus of the literature on co-optation in modern democracies, which regards co-optation as an attempt by democratic leaders to improve their ability to govern (Buchanan and Tullock 1962; Lehmbruch 1984, 1987). Co-optors bring in co-optees because the latter have the expertise, legitimacy, credibility or operative capacities needed for governance to be successful (Abbott et al. 2019). For instance, today's bureaucracies try to improve their administrative capacities by incorporating civil society actors with specific competencies into their administrative procedures (Buchanan and Tullock 1962; Lehmbruch 1987). Here, strategic co-optation is a governance technique.

(2) Internal vs. external challenges: Whether they are facing an authority or a governance challenge, co-optors may engage in co-optation to address internal or external challenges. If they co-opt to deal with internal challenges, they bring in the very actors that are challenging the order and the institutions they dominate. By means of co-optation, they try to turn challengers into supporters of the order and its institutions (Dickson 2008; Gerschewski 2013). The co-optation of German tribes - the Goths and later the Vandals - into the Roman Empire provides a good example of this. In the $4^{\text {th }}$ century, the frequent invasions by these tribes posed a serious challenge to the Empire. To cope with this challenge, the Emperor decided to make their leaders Roman citizens and give them the task of policing the Empire's borders, thus turning invaders into border guards (Wilson 2016, 37).

If co-optors deal with external challenges, they enlist co-optees to cope with challenges that stem from third parties. In this case, co-optation often amounts to a form of coalition building against a third-party challenge (Trotha 1994; Lake 2009). The Pope's co-optation of the Franks in the $8^{\text {th }}$ century serves as an example of this. The Pope required military support to protect the Church against its enemies. In return for Pepin the Short's military support, Pope Zachary crowned him Frankish king in 751, thereby sanctioning his coup against the Merovingians. In 800, Pope Leo III even crowned Pepin's successor, Charlemagne, Emperor of the Holy Roman Empire to gain his support against the Church's enemies. By means of co-optation, the Pope turned the Carolingians into defenders of the Church (Wilson 2016, 39-40).

Crossing the two distinctions, we derive four types of challenges (see Table 1). We claim that all the four types of fundamental challenges alter the cost-benefit assessments of would-be co-optors, thereby making co-optation possible. When faced with a fundamental challenge, co-optors' demands for additional support to stabilize the order will rise. The benefits of co-optation will increase relative to its costs. Co-optors might therefore be prepared to offer institutional privileges 
Table 1. Types of challenges and co-optor's reasons for co-optation

\begin{tabular}{ccc}
\hline & Authority challenge & Governance challenge \\
\hline $\begin{array}{c}\text { Internal challenge } \\
\text { (from co-opted } \\
\text { party) }\end{array}$ & $\begin{array}{c}\text { Taming opposition } \\
\text { (recognizing India's nuclear } \\
\text { power status in the NPT regime) }\end{array}$ & $\begin{array}{c}\text { Employing spoilers } \\
\text { (granting China } \\
\text { membership status in the } \\
\text { BCBS) }\end{array}$ \\
$\begin{array}{c}\text { External challenge } \\
\text { (from third party) }\end{array}$ & $\begin{array}{c}\text { Committing partners } \\
\text { (absorbing China into the WTO } \\
\text { core negotiation group) }\end{array}$ & $\begin{array}{c}\text { Enlisting competence } \\
\text { (increasing China's voting } \\
\text { shares in the IMF) }\end{array}$ \\
\hline
\end{tabular}

in return for co-optee support. By contrast, without such a challenge, co-optors have little incentive to co-opt others into the order they dominate. Why should they give out privileges for support they do not need? The benefits would not outweigh the costs. Thus, while certainly not sufficient, a fundamental challenge to the order appears to be necessary for co-optation to be possible. However, each type of challenge comes with a distinct reason why the benefits of co-optation may outweigh its costs (see Table 1). All four reasons feature prominently in cases of institutional adaptation to today's global power shifts.

Taming opposition: In the face of an internal challenge to their authority, co-optors may engage in co-optation to tame the opposition (Dickson 2000; Gandhi and Przeworski 2006; Hale 2015; Geddes et al. 2018). India's incorporation into the nuclear non-proliferation regime (or NPT regime) through its unofficial recognition as a nuclear power provides an example. India, among others, challenged the legitimacy of the NPT regime as it strictly enforced the commitment of non-nuclear states to refrain from seeking nuclear weapons, while at the same time largely ignoring the fact that states with nuclear weapons consistently violated their commitment to reduce their nuclear weapon arsenals. As a result, the NPT regime went through a severe authority crisis in the late 1990s and early 2000 s. Through India's unofficial recognition as a nuclear power - by means of the 2008 waiver of the Nuclear Suppliers Group (NSG) - the USA and other nuclear weapons states tried to tame India's opposition and contain the NPT regime's authority crisis (Mistry 2014; Perkovich 2010).

Employing spoilers: In the face of internal governance challenges, co-optors may employ as co-optees the same actors that are spoiling their governance efforts (Salehyan 2019; Tamm 2019). The inclusion of China in the Basel Committee on Banking Supervision (BCBS) provides an example (Knaack 2017). In the 1990s and 2000s, China's banking sector grew considerably. At the same time, China was not a member of the BCBS, compromising the BCBS's capacity to promulgate effective global standards for banking regulation. As a non-member, China's implementation of BCBS standards was slow and piecemeal. By offering China (and other emerging powers) BCBS membership in 2009, the USA and the EU addressed this internal governance challenge. A potential spoiler of the BCBS was incorporated into the global banking regulation order. As a result, China has turned 'from laggard to primus inter pares' (Knaack 2017, 50), introducing regulations that were even stricter than the recent Basel III standards demanded and implemented ahead of the agreed schedule. 
Committing partners: In the face of an external authority challenge, co-optors may engage in co-optation to commit partners to help them stabilize the order (Bertocchi and Spagat 2001). China's promotion as a member of the WTO core negotiation group provides an example. Soon after China became a WTO member in 2001, the USA and other established powers included China in the WTO core negotiation group - the so-called Quad. They did so with the expectation that China would help contain the authority challenge posed by India and Brazil, who had fought their way into the Quad. Established powers (erroneously) hoped that China, as a supporter of free trade, would contribute to reining in India's and Brazil's opposition and the obstructive tactics they used in the Doha Round negotiations, thus mitigating the authority challenge the latter posed to the WTO (Hopewell 2015).

Enlisting competence: Co-optors may also engage in co-optation to improve their ability to cope with an external governance challenge. In this case, they enlist competence (Abbott et al. 2019). The co-optation of China into the leadership of the IMF after the 2008 global financial crisis provides an example. The established powers, especially the USA, offered China an increase in its shares within the IMF's weighted voting system. They did so to convince China to shore up its financial support for the stabilization of a global financial system under stress (Wade 2011; Keukeleire and Hooijmaaijers 2014). Similarly, the 2007/08 upgrade of the G20 from a forum of finance ministers to a forum of heads of government served to enlist emerging economies' financial competencies to contain the global financial crisis (Wade 2011; Cooper and Thakur 2013; Kirton 2013).

To sum up, we highlight that a fundamental challenge to the order and its institutions is a necessary condition for strategic co-optation. Absent such a challenge, the co-optor's benefits will not outweigh the costs of co-optation. By distinguishing four types of challenges, we have also specified four distinct reasons why, in the face of a specific challenge, the benefits of co-optation may outweigh its costs.

\section{Co-optee availability as a probability driver}

A fundamental challenge to an order or its underlying institutions will hardly lead to co-optation if there are no co-optees that are both able and willing to provide the support needed to stabilize the order. For both co-optors and co-optees, the costs and benefits of co-optation - and, consequently, the incentive to engage in co-optation - depend on the degree to which potential co-optees are systemically relevant and the degree to which they agree with the social purpose of the existing order and its institutions. Therefore, we argue that the availability of co-optees that are systemically relevant for and in agreement with the social purpose of the existing order is the most important probability driver of strategic co-optation.

To begin with, co-optation is more likely when there are systemically relevant actors available that can be brought closer to the order's core leadership (Schmitter 1985). Systemic relevance implies that actors are not only powerful but that they have sufficient capabilities - material or ideational - to destabilize the order on their own and are, thus, critical for stabilizing the order (Viola 2018; Zürn 2018). Systemically relevant actors, in other words, can use their capacities to challenge the order or help to overcome challenges to it. Therefore, 
co-optors have an incentive to nurture - through co-optation - systemically relevant actors' interest in contributing to the maintenance of the order. This is the reason why autocrats typically co-opt the leadership of the most powerful opposition parties rather than the leaders of smaller opposition groups (Dickson 2000, 2008; Gandhi and Przeworski 2006). The availability of actors with systemic relevance will also enhance the incentives of these would-be co-optees to accept being co-opted. As systemically relevant actors, they have a bigger incentive to contribute to the stabilization of the order. As their support is crucial, freeriding on the contributions of others becomes impossible. With their support making $a$, if not the, difference to the stability of the order, their incentive to provide support in return for institutional privileges increases (Olson 1965).

However, the availability of actors with systemic relevance is unlikely to lead to co-optation if these actors do not agree on the social purpose and the fundamental principles of the order and its institutions (Johnson 2016; Abbott et al. 2019). Thus, co-optation is unlikely, if only revisionist or revolutionary actors are available. It becomes more likely, if there are reformist actors available. ${ }^{3}$ This makes co-optation easier for the co-optor because it can trust that the co-optee will not use its institutional privileges to revise the order's fundamental principles, let alone its social purpose. Moreover, co-optors have to offer less far-reaching privileges to gain support from co-optees that are in agreement with the purpose and principles of the existing order. This is also the reason why, in multi-ethnic states, the leaders of the ruling majority try to incorporate reform-minded, moderate leaders from minorities rather than radical or even revolutionary leaders (Pettai and Hallik 2002). They understand that moderates are easier and cheaper to co-opt than radicals. Likewise, co-optees who agree with the order's principles and purpose find it easier to accept being co-opted - in return for institutional privileges they 'merely' have to provide support for an order or an institution they basically agree with. Thus, the zone of agreement for a co-optation deal is much wider when there are co-optees available that agree with the order's social purpose and its fundamental principles (Abbott et al. 2019).

Overall, the availability of systemically relevant actors that agree with the social purpose and principles of the order shapes the probability of co-optation (see Table 2). This can be illustrated by comparing how, after World War II, Germany, France, and Italy co-opted the labor unions into their economic regimes (Scharpf 1978). Germany's governments co-opted them into their corporatist arrangements for managing the economy, because the labor unions were powerful monopoly organizations representing the bulk of laborers. This was crucial for the German governments' efforts at economic management. At the same time, they were moderate organizations that shared the governments' commitment to a coordinated market economy. In Italy and France, by contrast, the co-optation of labor unions was much more difficult, because none of the numerous competing

\footnotetext{
${ }^{3}$ Drawing on traditional PTTs (Organski 1968; Organski and Kugler 1980; Gilpin 1981), many PST contributions highlight the distinction between reformist (satisfied) and revisionist (dissatisfied) powers (Buzan 2010; Schweller 1994; Schweller and Pu 2011; Ward 2017). They typically underscore that institutional adjustments in response to global power shifts are easier to attain with reformist than revisionist powers (Buzan 2010; Paul 2016; Ward 2017). We agree but highlight that often these institutional adjustments come through strategic co-optation.
} 
Table 2. The availability of co-optees and the probability of co-optation

\begin{tabular}{ccc}
\hline \multicolumn{1}{c}{ Systemic relevance } & \multicolumn{1}{c}{ No systemic relevance } \\
\hline $\begin{array}{c}\text { Social purpose } \\
\text { agreed }\end{array}$ & $\begin{array}{c}\text { Co-optation of critical reformists: } \\
\text { likely } \\
\text { (recognizing India's nuclear } \\
\text { power status in the NPT regime) }\end{array}$ & $\begin{array}{c}\text { Co-optation of minor reformists: } \\
\text { unlikely } \\
\text { (granting the G4 permanent seats } \\
\text { in the UNSC) }\end{array}$ \\
$\begin{array}{c}\text { Social purpose } \\
\text { not agreed }\end{array}$ & $\begin{array}{c}\text { Co-optation of critical revisionists: } \\
\text { unlikely } \\
\text { (including the Soviet Union in } \\
\text { global economic institutions) }\end{array}$ & $\begin{array}{l}\text { Co-optation of minor revisionists: } \\
\text { very unlikely } \\
\text { (accepting G77 demands for a new } \\
\text { international economic order) }\end{array}$ \\
\hline
\end{tabular}

${ }^{a}$ In the 1970s, developing countries organized as Group of 77 (G77) called for a radically different New International Economic Order. But established powers largely rejected their demands for an overhaul of the Bretton Woods institutions and a substantial strengthening of the UN Conference on Trade and Development (UNCTAD), because the $\mathrm{G} 77$ was revisionist and not systemically relevant for global economic order.

organizations was powerful enough to help the French or Italian governments in their pursuit of managing the economy. Furthermore, significant parts of the Italian and French labor unions were more radical than their reformist German counterparts and they rejected the market economies in France and Italy.

The availability of able and willing co-optees also shapes the probability of co-optation in cases of global power shifts. Accordingly, India's rise to systemic relevance to the NPT regime and its agreement with the regime's social purpose were major conditions of its co-optation into the regime in the early 2000s. As a nuclear power with a fast-growing nuclear industry and leader of an increasingly vocal coalition of developing countries that criticized the NPT regime for being discriminatory, India became increasingly crucial - that is, systemically relevant - for the NPT regime (Perkovich 2010). At the same time, India had also supported the NPT regime's most fundamental principles and its social purpose, that is, nuclear non-proliferation. To be sure, India has always been a NPT regime critic, and had even acquired a nuclear device in the 1970s outside of the NPT (Paul and Shankar 2011). Nevertheless, despite its status as a non-signatory of the treaty, India was an unequivocal supporter of nuclear non-proliferation. In fact, its criticism was that the NPT regime required too little, rather than too much nonproliferation (Weiss 2010, 260-262). Due to India's agreement with the social purpose of the regime, the USA and other established powers were able to tap into its systemically relevant capacities to stabilize the NPT regime when it was under threat (Perkovich 2010).

Similarly, China's co-optation into the leadership of the IMF was facilitated by the fact that China was systemically relevant for global financial stability and also accepted the promotion of global financial stability as the IMF's social purpose (Ren 2015). China's co-optation into the WTO and its later inclusion in the core negotiation group was facilitated by its acceptance of the WTO's free trade principle, while at the same time its huge share of global trade made it systemically relevant for the WTO (Hopewell 2015). The co-optation of BIC countries into the leadership of global economic governance by means of a G20 upgrade was facilitated by the growing systemic relevance of BIC economies as well as their increasing acceptance of the global order's liberal economic principles (Kirton 2013). 
By contrast, the co-optation of the G4 (Germany, Japan, India, and Brazil) as permanent members of the UNSC failed not only due to third party resistance, but also because the G4, while being in strong agreement with the social purpose of the UNSC, lacked systemic relevance for the UNSC. To be sure, the G4's inclusion would have helped us to mobilize additional financial and military resources especially for peacekeeping (Blum 2005); but they were not critical for the functioning of the UNSC. This limited the amount of costs established powers were willing to bear and thus the efforts they were ready to make to bring about co-optation.

In sum, for co-optation to be likely, emerging powers need to be more than just increasingly powerful. They are increasingly powerful by definition! They should also have crossed the threshold of systemic relevance and be in agreement with the social purpose of the existing order. They should be critical reformists rather than minor revisionists.

\section{Third-party resistance as a probability driver}

So far, we have assumed that the probability of co-optation depends exclusively on whether the co-optor and co-optee can find a co-optation agreement between themselves. However, more often than not, the probability of co-optation also depends on the acceptance of, or resistance to, co-optation by third parties. After all, many co-optation accounts show that co-optation is detrimental to third parties that are not part of the co-optation deal (Schmitter 1985; Lehmbruch 1987). Therefore, we conceive co-optation parties' institutional opportunities to overcome third-party resistance as an important probability driver.

More often than not, third parties resist the exchange of privileges for support, thereby increasing the costs and reducing the benefits of co-optation. Disregarded candidates for co-optation in particular try to prevent the co-optation deal envisioned by the co-optor and co-optee (Bolliger and Zürcher 2004; Wilson 2016). They fear loss of status, influence and authority relative to the chosen co-optee. For instance, the co-optation of additional German princes into the electorate that selected the King of the Holy Roman Empire - that is, the prospective Emperor - was typically met with fierce resistance from the princes who had been hoping to become members of the electorate themselves (Wilson 2016).

The same pattern of 'third-party resistance' can be identified when, in the wake of global power shifts, established powers try to co-opt emerging powers into the international order and its institutions. The co-optation of the BIC countries into the core leadership group of global economic governance through an upgrade of the G20 was met with resistance from powers such as Switzerland and Singapore that had not been invited to join the club (Cooper 2010; Cooper and Thakur 2013). The attempted co-optation of the G4 into the club of the UNSC's permanent members faced resistance from, among others, Italy, which opposed the granting of a permanent seat to Germany (Blum 2005, 646; Schirm 2010). China's co-optation into the IMF leadership through an increase in its voting shares was resisted by some European powers that had to accept a decrease in their own (Wade 2011; Keukeleire and Hooijmaaijers 2014). Finally, India's co-optation into the NPT regime was met with resistance from a group of like-minded states that were led 
Table 3. Third-party resistance and the probability of strategic co-optation

\begin{tabular}{ccc}
\hline & $\begin{array}{c}\text { Third parties have } \\
\text { weak veto power }\end{array}$ & $\begin{array}{c}\text { Third parties have } \\
\text { strong veto power }\end{array}$ \\
\hline $\begin{array}{c}\text { Co-optation parties } \\
\text { have ample outside } \\
\text { options }\end{array}$ & $\begin{array}{c}\text { Co-optation by layering: very } \\
\text { likely } \\
\text { (including the BICS in the club } \\
\text { of leading economies via G20 } \\
\text { upgrade) }\end{array}$ & $\begin{array}{c}\text { Co-optation by shifting: quite } \\
\text { likely } \\
\text { (recognizing India's nuclear } \\
\text { power status in the NPT } \\
\text { regime) }\end{array}$ \\
$\begin{array}{c}\text { Co-optation parties } \\
\text { have few outside } \\
\text { options }\end{array}$ & $\begin{array}{c}\text { Co-optation by overruling: likely } \\
\text { (increasing China's voting } \\
\text { shares in the IMF) }\end{array}$ & $\begin{array}{c}\text { Co-optation by breaking: } \\
\text { unlikely } \\
\text { (granting the G4 permanent } \\
\text { seats in the UNSC) }\end{array}$ \\
\hline
\end{tabular}

by New Zealand and comprised of Austria, Ireland, the Netherlands, Norway, and Switzerland (Varadarajan 2008; Mistry 2014, 187).

The more resistance third parties can generate, the higher the costs of co-optation for co-optors and co-optees as they must find ways to overcome this resistance. In extreme cases, the costs of overcoming third-party resistance may prevent co-optation altogether. At any rate, third-party resistance shapes the probability of co-optation as co-optors and co-optees must consider it in their cost-benefit calculation. In our view, the ability of the co-optation parties to overcome thirdparty resistance primarily depends on two institutional conditions (cf. Mahoney and Thelen 2010). It depends, first, on third party veto power within the relevant institution (Tsebelis 2002; Mahoney and Thelen 2010). The stronger (weaker) the veto power of third parties, the more (less) costly it will be to overcome their resistance which, in turn, makes co-optation less (more) likely. Second, it depends on the co-optation parties' options for co-optation outside the institution in question (Alter and Meunier 2009; Helfer 2009; Morse and Keohane 2014; Lipscy 2017). The broader (narrower) those options are, the less (more) costly it will be to overcome third-party resistance which, in turn, makes co-optation more (less) likely. In combination, these institutional conditions not only shape the costs of overcoming third-party resistance and thus the probability of co-optation; but they also shape co-optation parties' strategies to overcome third-party resistance (see Table 3).

Breaking: In institutional settings where third parties have strong veto power and co-optation parties have few opportunities for co-optation outside of the institution in question, co-optation is very unlikely. Third parties are able to block any attempt at adjusting the institution in ways that give the co-optee more privileges in return for increased support, while the co-optation parties cannot simply move to another institutional venue. Locked into the institutional status quo, the only option the co-optation parties have is to break the resistance of recalcitrant third parties (Lipscy 2017). Yet, breaking resistance is usually costly and, consequently, co-optation is likely to fail under such circumstances.

The failed attempt to co-opt the G4 - Brazil, India, Germany, and Japan - into permanent positions in the UNSC is illustrative. The G4's ambitions faced resistance from Italy, which opposed a permanent seat for Germany, from South Korea, which expressed opposition to a Japanese seat, from Argentina, which was opposed to a seat for Brazil, and from Pakistan, which rejected an Indian seat (Blum 2005, 646; Schirm 
2010). These countries organized a veto coalition to ensure that the G4's ambitions would not gain the approval it required from the UN General Assembly (UNGA). At the same time, the permanent members of the UNSC and the G4 had no outside option. In international security, especially with regard to the legitimization of peacekeeping and peace-enforcement, the UNSC has a constitutionally guaranteed monopoly (Lipscy 2017). The G4 consequently tried to break resistance by offering third countries trade concessions or threatening trade sanctions to muster the necessary UNGA votes. In the end, this strategy was too costly, and the G4 had to give up their ambition of gaining permanent UNSC seats in return for their substantive support of UN peace-missions (Blum 2005, 646; Schirm 2010).

Shifting: In institutional settings where reluctant third parties have strong veto power but co-optation parties enjoy broad outside options, co-optation is somewhat more likely. While recalcitrant third parties can prevent internal institutional adjustments that give co-optees additional institutional privileges, the co-optation parties may shift to another institutional venue thereby circumventing third-party resistance (Alter and Meunier 2009; Helfer 2009; Morse and Keohane 2014). While shifting is costly, it is typically less costly than breaking third-party resistance (Jupille, Mattli and Snidal 2013). The availability of such outside options thus reduces the costs of overcoming resistance (Lipscy 2017). This renders co-optation more likely.

India's co-optation into the NPT regime provides an example. The USA supported by the UK, France, and Russia - never really considered fully recognizing India under the NPT as a nuclear weapons state. Due to third-party resistance, the required amendment to the NPT would have had no chance of being approved, since it required the consent of 189 NPT member states. However, the wider NPT regime gave the USA and India the option to seek unofficial recognition of India as a nuclear power through an NSG waiver. The recognition of India's status as a nuclear power also met resistance in the NSG. In fact, the USA and India had to break considerable resistance from some NSG members to secure the required waiver (Varadarajan 2008). Still, by shifting from the NPT to the NSG, they were able to circumvent the bulk of the resistance to recognizing India as a nuclear weapon state. After all, the NSG had only 45 members compared with the NPT's 189. Moreover, all NSG members were developed countries with nuclear industries. These states could profit from nuclear trade with India and were thus less resistant to recognizing India as a nuclear power than the developing countries without such industries that were parties to the NPT. The latter had argued for years - as had India - that the NPT's distinction between nuclear-weapons states and non-nuclear-weapon states was discriminatory (Srivastava and Gahlaut 2012, 101102). Shifting to the NSG thus facilitated India's co-optation into the NPT regime.

Overruling: Co-optation is likely in institutional settings in which reluctant third parties have no veto power to block the co-optation parties' exchange of institutional privileges for support. This even holds when the co-optation parties have few options to engage in co-optation outside the institution in question. Overcoming third-party resistance is less costly when disregarded candidates for co-optation have no veto power that would allow them to block the co-optation agreement. Within the institution, third parties can be overruled if the co-optation parties command a constructive majority. As third parties will usually understand that, without veto power, they 
have little leverage, the mere threat of overruling them may be sufficient for the co-optation parties to bring them in line (Lipscy 2017).

China's co-optation into the IMF leadership through an increase in its voting shares provides an example. While some European powers that stood to lose voting shares tried to prevent the required IMF reform, they did not constitute a blocking minority and thus had no veto power. Even in the absence of options outside of the IMF, the constructive majority that wanted China to be co-opted into the IMF leadership was able to push through the required reforms. The recalcitrant European powers could do little but accept the decrease in their respective voting rights. They were not in a position to stop the granting of additional voting rights in return for China's increased financial IMF support (Wade 2011; Keukeleire and Hooijmaaijers 2014).

Layering: Co-optation is even more likely in an institutional setting where not only do reluctant third parties have little veto power, but co-optation parties enjoy ample options to engage in co-optation beyond the focal institution. These settings offer co-optors and co-optees very good opportunities to overcome thirdparty resistance. They may simply overrule recalcitrant third parties; alternatively, they may shift to another institution. However, both overruling and shifting typically create costs. Shifting creates transaction costs and undermines the original institution's authority; overruling typically alienates overruled third parties and may thus create legitimacy costs. To minimize these costs, co-optation parties may go for layering to overcome third-party resistance. Layering implies that the co-optee gains institutional privileges within the original institution, rather than in an outside institution to which the co-optation parties have shifted. However, instead of pushing through a conversion of existing institutional structures, new institutional structures are layered on top of the existing ones (Mahoney and Thelen 2010). In this way, co-optees can gain institutional privileges without taking pre-existing privileges away from other actors.

Arguably, the co-optation of the BICs into the core leadership of global economic governance in 2008 was easy to achieve because candidate co-optees such as Switzerland and Singapore had no veto power to block the concomitant upgrading of the G20. Moreover, the G7 had several options available. Instead of upgrading the G20 from a forum of finance ministers to a forum of heads of government or state, they could have enlarged the membership of the existing G7. Alternatively, an entirely new group could have been created to complement both the G7 and the G20. In the end, they decided to layer an upgraded G20 on top of the pre-existing forum of finance ministers. Layering was less costly than the alternatives, as it saved the G7 from discussions about who should become a member of their exclusive club. Through the decision to upgrade the G20, the membership issue was automatically settled (Cooper 2010; Cooper and Thakur 2013).

Overall, our co-optation theory highlights that institutional adjustments to global power shifts often do not simply require the consent of established and emerging powers. Third-party resistance may cause them to fail. Emerging and established powers' institutional opportunities to overcome their resistance, thus, have a strong impact on the probability of strategic co-optation. 


\section{Unintended consequences: dynamic instabilities of strategic co-optation}

Co-optation is a strategy used to stabilize order in the face of fundamental challenges and it can remain stable over time. Bismarck's co-optation of the Catholic and Protestant churches into the German nation-state after the so-called Kulturkampf in the 1870s is still in place today. Similarly, the co-optation of labor unions and employer associations into European welfare states lasted for about five decades. The stability of these co-optation arrangements is easy to explain. Like any institution, co-optation gains endogenous stability through lock-in effects and increasing returns. From this institutionalist point of view, co-optation becomes harder and harder to overthrow and thus more and more stable over time (Pierson 2000).

While not denying that co-optation arrangements can remain stable over time, our theory of strategic co-optation claims that co-optation arrangements do, at times, become unstable. The exchange of institutional privileges for institutional support is not always self-stabilizing; sometimes it proves to be self-undermining. Paradoxically, the success of co-optation can lead to its failure (cf. Abbott et al. 2019). Co-optation occasionally has unintended consequences that may, over time, contribute to its destabilization. In what follows we discuss how the support provided by the co-optee on the one hand and the privileges granted to it on the other may feed unintended consequences that undermine the stability of the initial arrangement.

\section{Support-driven instability}

Paradoxically, the support provided by the co-optee may ultimately destabilize the co-optation arrangement that initially gave rise to it. The more that support contributes to overcoming the fundamental challenge that provided the rationale for the co-optor and the co-optee to engage in co-optation, the more co-optation contributes through various feedback loops to its own demise. Depending on whether support from the co-optee is able to resolve the fundamental challenge entirely or merely contain it temporarily, different kinds of endogenous instabilities may emerge:

(1) If support from the co-optee resolves rather than simply contains the fundamental challenge, the co-optor is likely to resile from the initial arrangement. In this case, the co-optor's need for continued support from the co-optee diminishes. The less the co-optor requires support, the more it gains leverage over the co-optee and may push for the rescission of the institutional privileges that the co-optee gained through co-optation. The initial co-optation deal comes under pressure, because, thanks to its success in mobilizing support for overcoming the fundamental challenge, the co-optor can do without the co-optee. For example, the USA co-opted the Kurds in Syria to provide support in its war against the so-called Islamic State. However, once it considered this war to be won, the Trump administration was no longer prepared to protect the Kurds against the Syrian and Turkish armies (Nordland 2018).

This support-driven feedback, which provides the co-optor with leverage over the co-optee, is also relevant to co-optation in the wake of the current global 
power shifts. Among other things, the BICs were co-opted into the core leadership of global economic governance to cope with the challenges of the 2008 global financial crisis (Cooper 2010; Cooper and Thakur 2013). However, once the BICs and other emerging economies had contributed to getting the financial crisis under control, they were no longer needed to the same extent. The G7 was unable to officially downgrade the G20 and thus rescind the BICs' privilege of membership in the leadership group of global economic governance. Nonetheless, they began re-emphasizing and upgrading the G7's status as the key forum of global economic governance. With the re-emergence of the G7, the co-optation arrangement has been at least partially undone.

(2) However, institutional support does not necessarily contribute to the restoration of the co-optor's dominance. If the support provided by the co-optee proves enough to contain, but not resolve, the fundamental challenge that motivated the initial co-optation deal, the co-optee may resile from the existing co-optation arrangement. Containing the challenge implies that the co-optor continues to need support, so the co-optee will gain leverage to push for a revised co-optation deal with additional institutional privileges. This is all the more likely if the co-optor becomes accustomed to the co-optee's support and less able or willing to mobilize support from elsewhere. The initial co-optation deal comes under pressure, because the co-optor can - and probably will - push for more and more privileges. This may lead to the point where the co-optor has no more privileges left to grant. The Holy Roman Empire provides an example. To deal with challenges to his authority, the Emperor continuously had to co-opt some of the princes by giving them control over additional territories as fiefdoms. However, not only was the amount of territory he could give out limited, but, through the increase in the territory they controlled, the princes gained greater power to contest the Emperor's authority, which in turn increased the Emperor's need for support. The more he needed support, the more the princes gained leverage to push for more privileges in return until, finally, one of the princes was powerful enough to capture the crown (Wilson 2016).

This support-driven feedback, which gives leverage to the co-optee, is relevant for co-optation in the wake of the current global power shifts as well. For example, the more China has been co-opted into the US-led global financial order that is bolstered by the IMF and other institutions, the more the USA and other established powers have become dependent on Chinese support in managing the global financial system - not only in times of crisis but also in 'normal' times. Consequently, China is positioned to gain ever more procedural and substantive privileges in the IMF and other global financial institutions. Examples of newly gained Chinese privileges include a more favorable IMF surveillance system (Zangl et al. 2016) and IMF recognition of the legitimacy of capital controls (Chwieroth 2014), and of the Chinese currency, the Renminbi, as one of the institution's reserve currencies. This underlines how institutional support may give emerging powers leverage over established powers and thus destabilize the initial co-optation arrangement. 


\section{Privileges-driven dynamics}

It is not only the institutional support provided by the co-optee, but also the institutional privileges it gains that may ultimately destabilize the co-optation arrangement that prompted the granting of these privileges. The privileges initially have a stabilizing effect as they give the co-optee a stake in maintaining the order and in providing the support the co-optor seeks. However, over time, the more the interests of the co-optor and the co-optee converge on maintaining the extant order and its underpinning institutions, the greater the risk that third parties perceive the co-optor and co-optee as an elite cartel that uses the existing order and its institutions to dominate them politically or exploit them economically (Lazar 2017). Over time, this feedback may intensify third-party resistance and broaden it well beyond the initial resistance of disregarded candidates for co-optation. Co-optation may even breed (more) resistance among the constituencies of both co-optation parties (Dickson 2000), reducing the overlap of their 'win-sets' (Putnam 1988) and thus endangering the continuation of the original co-optation arrangement (Bolliger and Zürcher 2004, 62-63).

(1) The institutional privileges co-optees gain through co-optation may drive a wedge between them and their own constituencies (Bolliger and Zürcher 2004, 62-63; Lake 2016). The more institutional privileges they gain, the more they run the risk of their own constituencies regarding them as part of a distant elite cartel (Dickson 2000). They may be conceived as being focused on their institutional privileges and losing touch with their constituencies. For instance, union leaders co-opted by the state are no longer seen as representing the workers (Lazar 2017), while local state-builders co-opted by foreign powers are no longer considered as representing the local population (Lake 2016). In these cases, the institutional privileges for group leaders drive a wedge between privileged co-optees and the ordinary group members they are expected to represent. This may endanger existing co-optation arrangements if radicalized constituencies become unwilling to follow their co-opted leaders or if these leaders feel the urge to reduce their support for the existing order to show loyalty to their radicalized constituencies.

This privileges-driven feedback is also relevant for co-optation in the wake of the current global power shifts. For example, China's co-optation in the mid-2000s following the inclusion of Brazil and India into the WTO core negotiation group - the so-called Quad - did not placate developing countries' criticism of illegitimate WTO procedures (Hopewell 2015; Zangl et al. 2016). Quite the opposite! Developing countries expected China to act as a genuine representative of their concerns in the WTO. When they learned that China was ready to strike deals with the USA and the EU in closed-door negotiations rather than advocate for their concerns, criticism of illegitimate WTO procedures intensified among developing countries. China, India, and Brazil were criticized for betraying their constituencies: they had relied on their role as the voice of developing countries to get into the privileged inner circle of WTO decision-making, but ceased to represent developing countries' interests once they were in the club. The emerging powers then sought to redress the alienation of their constituencies by taking a more confrontational stance towards established powers. This, in turn, put a strain on the Doha Round negotiations, thereby endangering the initial co-optation deal 
which was meant to overcome the blockade at the Doha Round (Hopewell 2015; Zangl et al. 2016).

(2) The institutional privileges granted to a co-optee may not only drive a wedge between it and its constituency, but they can also alienate the constituencies of the co-optor (Dickson 2000). The more co-optors grant institutional privileges to their co-optees, the greater the risk that their constituencies will perceive them as engaging in dodgy deals (Bolliger and Zürcher 2004, 62-63). This risk is particularly severe when co-optors co-opt leaders of groups that are strongly opposed by their own constituencies. For example, governments in young democracies run the risk of being considered traitors by their voters if they co-opt police chiefs who collaborated with authoritarian governments in the past (Fichtelberg 2018). In such cases, the granting of institutional privileges to leaders of groups to whom the co-optor's constituencies are in stark opposition may drive a wedge between the co-opting politicians and their constituencies. This is likely to endanger existing co-optation arrangements if radicalized constituencies are no longer willing to support them or if leaders feel that they have to reduce the institutional privileges given to co-optees or force them to increase their support to rein in their radicalized constituencies.

This privileges-driven instability is also relevant for co-optation in the wake of the ongoing global power shifts. One may argue, for instance, that the decades-long co-optation of lesser powers into the US-led world order has contributed to growing anti-internationalist sentiments in the USA (Lake 2009; Zürn 2018). In this view, increasing sections of the USA electorate have become increasingly opposed to the costly granting of institutional privileges to an expanding number of allies, whom they often perceive as either contributing too little support for the US-led order or as being in opposition to American values or interests. In the wake of the current power shift, the American electorate's uneasiness with the US-led order has fed into US President Trump's allegations that, in the context of international institutions, some of his predecessors acted in the interests of America's international allies, with whom they formed an internationalist liberal elite cartel, instead of acting in America's own best interests (Toma 2018). His 'America First' foreign policy can thus be seen as the attempt to retrench the co-optation arrangements that backed the US-led world order and its institutions.

In sum, while strategic co-optation is subject to endogenous stabilities, it is also exposed to endogenous instabilities. While not denying - and in fact assuming! that co-optation is often stable over time, we highlight that both institutional support from, and institutional privileges for, emerging powers may undermine the initial co-optation arrangement. However, as of now, the conditions under which these endogenous instabilities override co-optation's endogenous stability remain subject to further research.

\section{Strategic co-optation beyond global power shifts}

Drawing on several isolated accounts of strategic co-optation from other domains domestic and international, autocratic and democratic, past and present - we have developed a theory of strategic co-optation as a mode of institutional adaption to shifts in the global distribution of power. Our theory differs in important ways 
Table 4. Three approaches to institutional adjustments to global power shifts

\begin{tabular}{|c|c|c|c|}
\hline & $\begin{array}{c}\text { Accommodationist } \\
\text { approach }\end{array}$ & $\begin{array}{l}\text { Integrationist } \\
\text { approach }\end{array}$ & $\begin{array}{l}\text { Co-optation } \\
\text { approach }\end{array}$ \\
\hline $\begin{array}{l}\text { Power shifts } \\
\text { create } \\
\text { pressure for } \\
\text { institutional } \\
\text { adjustment } \\
\text { due to ... }\end{array}$ & $\begin{array}{l}\text {... internal authority } \\
\text { challenges: rising } \\
\text { powers will challenge } \\
\text { the institution's } \\
\text { authority. }\end{array}$ & $\begin{array}{l}\text {... external } \\
\text { governance } \\
\text { challenges: } \\
\text { declining powers } \\
\text { cannot sustain } \\
\text { needed } \\
\text { institutional } \\
\text { support. }\end{array}$ & $\begin{array}{l}\text {... fundamental } \\
\text { challenges: } \\
\text { external or } \\
\text { internal, } \\
\text { governance or } \\
\text { authority } \\
\text { challenges. }\end{array}$ \\
\hline $\begin{array}{l}\text { Institutional } \\
\text { adjustments } \\
\text { to global } \\
\text { power shifts } \\
\text { will be... }\end{array}$ & $\begin{array}{l}\text {... one-sided } \\
\text { accommodation } \\
\text { through established } \\
\text { powers' offer of } \\
\text { institutional } \\
\text { privileges. }\end{array}$ & $\begin{array}{l}\text {.. one-sided } \\
\text { adjustment of } \\
\text { emerging } \\
\text { powers to the } \\
\text { institutions they } \\
\text { are willing to } \\
\text { support. }\end{array}$ & $\begin{array}{l}\text {... mutual: } \\
\text { established and } \\
\text { emerging powers } \\
\text { trade institutional } \\
\text { privileges for } \\
\text { support. }\end{array}$ \\
\hline $\begin{array}{l}\text { Established } \\
\text { powers } \\
\text { accept } \\
\text { institutional } \\
\text { adjustments } \\
\text { to } \ldots\end{array}$ & $\begin{array}{l}\text {... stabilize the } \\
\text { institution's authority } \\
\text { and prevent a future } \\
\text { institutional } \\
\text { overhaul. }\end{array}$ & $\begin{array}{l}\text {... stabilize the } \\
\text { institution's } \\
\text { governance by } \\
\text { garnering } \\
\text { emerging } \\
\text { powers' support. }\end{array}$ & $\begin{array}{l}\text {... stabilize the } \\
\text { institution's } \\
\text { authority and/or } \\
\text { governance by } \\
\text { enlisting } \\
\text { systemically } \\
\text { relevant powers. }\end{array}$ \\
\hline $\begin{array}{l}\text { Emerging } \\
\text { powers' } \\
\text { acceptance of } \\
\text { institutional } \\
\text { adjustments } \\
\text {... }\end{array}$ & $\begin{array}{l}\text {... decreases with their } \\
\text { rise as they become } \\
\text { increasingly able to } \\
\text { overthrow the } \\
\text { institution. }\end{array}$ & $\begin{array}{l}\text {... increases with } \\
\text { their rise as they } \\
\text { gain a stake in } \\
\text { maintaining the } \\
\text { institution. }\end{array}$ & $\begin{array}{l}\text {... depends on their } \\
\text { acceptance of the } \\
\text { institution's social } \\
\text { purpose and } \\
\text { principles. }\end{array}$ \\
\hline $\begin{array}{l}\text { Third parties' } \\
\text { impact on } \\
\text { institutional } \\
\text { adjustment is } \\
\text {... }\end{array}$ & $\begin{array}{l}\text {... irrelevant, because } \\
\text { emerging and } \\
\text { established powers } \\
\text { are in control. }\end{array}$ & $\begin{array}{l}\text {... irrelevant, } \\
\text { because } \\
\text { emerging and } \\
\text { established } \\
\text { powers are in } \\
\text { control. }\end{array}$ & $\begin{array}{l}\text {... important, } \\
\text { because third } \\
\text { parties can block } \\
\text { institutional } \\
\text { adjustment. }\end{array}$ \\
\hline $\begin{array}{l}\text { Institutional } \\
\text { stability over } \\
\text { time depends } \\
\text { on ... }\end{array}$ & $\begin{array}{l}\text { whether the power } \\
\text { shift continues } \\
\text { (exogenous sources of } \\
\text { instability). }\end{array}$ & $\begin{array}{l}\text {... emerging } \\
\text { powers' } \\
\text { socialization } \\
\text { into the } \\
\text { institution } \\
\text { (endogenous } \\
\text { sources of } \\
\text { stability). }\end{array}$ & $\begin{array}{l}\text {... privileges- and } \\
\text { support-driven } \\
\text { dynamics } \\
\text { (endogenous } \\
\text { sources of } \\
\text { instability). }\end{array}$ \\
\hline
\end{tabular}

from extant PSTs of liberal (integrationist) or realist (accommodationist) origin (see Table 4):

Conceptually, we have highlighted that institutional adjustments through co-optation imply that established and emerging powers trade institutional privileges for institutional support. Unlike accommodationist approaches, which focus on how established powers have to accommodate emerging powers through 
institutional privileges (Paul 2016), and integrationist approaches, which underline that emerging powers adjust themselves to the existing order (Ikenberry 2009, 2011a, b), our co-optation theory emphasizes their mutual adjustment.

Our theory highlights three conditions as causes of strategic co-optation:

- Fundamental challenge: Co-optation is only possible if there is a fundamental challenge to the existing order. Yet, in contrast to accommodationist and integrationist PSTs, our institutionalist theory grasps the broad range of challenges that an institutional order may face. While accommodationists identify internal authority challenges (Kirshner 2012; Paul 2016) but overlook both external and governance challenges, integrationists seem to assume that external governance challenges are of paramount importance (Ikenberry 2009; 2011a; b) while ignoring both internal challenges and challenges to authority. We, on the other hand, consider the full set of relevant challenges - to authority and governance as well as internal and external.

- Co-optee availability: Co-optation is only likely if there are both willing and able co-optees. However, in contrast to many PST contributions, our co-optation theory conceives the systemic relevance of emerging powers (i.e. their ability) and their agreement with the social purpose of the existing order (i.e. their willingness) as - at least partly - independent of each other. Accommodationist PSTs assume that the more powerful, and consequently able, emerging powers are, the less willing they will be to stabilize the order (Schweller and $\mathrm{Pu}$ 2011). Integrationist PSTs presume that the more capable emerging powers become, the more of a stake they have in sustaining the order and the more willing they will be to contribute to stabilizing it (Ikenberry 2009; 2011a; b). By contrast, we argue that emerging powers' willingness to stabilize the order cannot simply be derived from their power and thus their ability to do so. Their ability and their willingness have to be assessed empirically and independently of each other.

- Third-party resistance: Co-optation is only likely if the institutional setting allows the co-optation parties to overcome third-party resistance. Unlike existing PSTs - both accommodationist and integrationist - our theory highlights that institutional adjustments to shifts in the global distribution of power often require more than just the consent of established and emerging powers. Due to third-party resistance, such adjustments may fail even in cases where emerging and established powers agree. Therefore, we have specified the institutional conditions under which it is likely that resistance to institutional adjustments can be overcome.

Furthermore, with regard to the (unintended) consequences of strategic co-optation, our theory diverges from both accommodationist and integrationist PSTs in that it sheds light on endogenous dynamics leading to instability. Integrationist PSTs argue that, through integration, emerging powers will be progressively socialized into an existing order that was created and maintained and is still dominated - by established powers. They thus underline endogenous sources of stability (Ikenberry 2009, 2011a, b). Accommodationist PSTs highlight the fact that established powers' accommodation of emerging powers will likely 
stabilizes the order only temporarily (Kirshner 2012). If the current power shift continues, today's accommodation will come under pressure tomorrow. Hence, they underline exogenous sources of instability. While we agree with both accounts, our theory also identifies endogenous sources of instability.

Strategic co-optation is neither omnipresent nor a panacea for adapting international institutions to global power shifts. But it is important enough to warrant its own approach. Theoretically coherent and conducive to empirical assessment, our co-optation theory paves the way to a systematic analysis of strategic co-optation in the wake of global power shifts.

Here we have merely tried to illustrate, through a variety of examples, that the theory is well placed to shed light on how international institutions adapt to shifts in the global distribution of power. Yet, to rigorously and comprehensively assess the theory, more comparative research is required that studies international institutions that are subject to global power shifts. One way of doing this would be to study international institutions in which, in the context of the current global power shift with the rise of China and the relative decline of the USA, one of our conditions - fundamental challenge, co-optee availability, third party resistance varies over time and check whether this has the expected effect with regard to institutional adjustment. Another way to assess our theory would be to rely on a systematic comparison across a variety of international institutions in which China has risen and the USA has experienced relative decline. One would have to assess whether institutional adjustment is significantly more frequent in those institutions in which the conditions specified by our theory - fundamental challenge, co-optee availability, institutional opportunities to overcome third party resistance - are present.

Finally, yet another way to assess our theory would be to apply it even in political domains beyond the adjustment of international institutions to global power shifts. As the above examples ranging from authoritarian regimes to corporatist arrangements and colonial empires suggest, our theory might well be suitable to explain the adjustment of all kinds of institutionalized settings in which dominant actors are facing power shifts that favor other actors. In all these settings, granting privileges in return for rising actors' institutional support appears as a rational strategy with which dominant actors can seek to stabilize the institutional status quo. And in all these settings co-optation seems to depend on whether existing institutions face a fundamental challenge to their authority or governance, whether rising actors are both systemically relevant for the institution and in agreement with its social purpose, and whether third parties have the opportunity to block the institutional adjustments that any co-optation deal between declining and rising actors entails. Applying our theory to instances of co-optation beyond the domain of institutional adaptation to global power shifts thus promises new analytical insights on the relevant phenomena and considerably enhances the reservoir of cases that could be used to test our theory.

Acknowledgments. We thank the editors of IT, the anonymous reviewers, Martin Binder, Philipp Genschel, Tim Heinkelmann-Wild, Christian Kreuder-Sonnen, and the participants of workshops and research colloquia in Berlin, Florence, Freising, and Munich for their very helpful comments on earlier versions of this paper. 


\section{References}

Abbott, Kenneth, Philipp Genschel, Duncan Snidal, and Bernhard Zangl. 2019. "Competence versus Control: The Governor's Dilemma.” Regulation \& Governance, online first, 4 January 2019. https:// doi.org/10.1111/rego.12234.

Abdullah, Walid Jumblatt. 2015. "Of Co-Optation and Resistance. Stata-Olama Dynamics in Singapore." Journal of Church and State 58:462-82.

Acharya, Amitav. 2014. "Multilateralism: Beyond Hegemony and Without Victory." In Rethinking Power, Institutions and Ideas in World Politics: Whose IR? edited by Amitav Acharya, 141-58. London: Routledge.

Alter, Karen J., and Sophie Meunier. 2009. “The Politics of International Regime Complexity.” Perspectives on Politics 7:13-24.

Baur, Dorothea, and Hans-Peter Schmitz. 2012. "Corporations and NGOs: When Accountability Leads to Cooptation." Journal of Business Ethics 106:9-21.

Bertocchi, Graziella, and M. Michael Spagat. 2001. "The Politics of Co-Optation." Journal of Comparative Economics 29:591-607.

Blum, Yehuda Z. 2005. "Proposals for UN Security Council Reform." The American Journal of International Law 99:632-49.

Bolliger, Christan, and Regula Zürcher. 2004. "Deblockierung Durch Kooptation? Eine Fallstudie zur Aufnahme der Katholisch-Konservativen in die Schweizerische Landesregierung 1891." Swiss Political Science Review 10:59-92.

Brooks, Stephen G., and William C. Wohlforth. 2015/2016. "The Rise and Fall of the Great Powers in the Twenty-first Century: China's Rise and the Fate of America's Global Position.” International Security 40:7-53.

Buchanan, James M., and Gordon Tullock. 1962. The Calculus of Consent: Logical Foundations for Constitutional Democracy. Ann Arbor, MI: The University of Michigan Press.

Buzan, Barry. 2010. "China in International Society. Is 'Peaceful Rise' Possible?" The Chinese Journal of International Politics 3:5-36.

Chwieroth, Jeffrey. 2014. "Controlling Capital: The International Monetary Fund and Transformative Incremental Change from within International Organisations." New Political Economy 19:445-69.

Cooper, Andrew F. 2010. "The G20 as an Improvised Crisis Committee and/or a Contested 'Steering Committee' for the World." International Affairs 86:741-57.

Cooper, Andrew F., and Ramesh Thakur. 2013. The Group of Twenty (G20). London: Routledge.

Crowder, Michael. 1964. "Indirect Rule: French and British Style." Africa: Journal of the International African Institute 34:197-205.

Daßler, Benjamin, Andreas Kruck, and Bernhard Zangl. 2019. "Interactions Between Hard and Soft Power. The Institutional Adaptation of International Intellectual Property Protection to Global Power Shifts." European Journal of International Relations 25:588-612.

Dickson, Bruce J. 2000. "Co-Optation and Corporatism in China: The Logic of Party Adaptation." Political Science Quarterly 115:517-40.

Dickson, Bruce J. 2008. Wealth into Power: The Communist Party's Embrace of China's Private Sector. Cambridge: Cambridge University Press.

Easton, David. 1975. "A Re-Assessment of the Concept of Political Support." British Journal of Political Science 5:435-57.

Fichtelberg, Aaron. 2018. Carolingians on the Beat: Democratic Policing and Competence-Control Theory (Paper presented at a workshop on the Governor's Dilemma at the European University Institute in Florence, May 14-15, 2018).

Gandhi, Jennifer, and Adam Przeworski. 2006. "Cooperation, Co-Optation and Rebellion Under Dictatorships." Economics and Politics 18:5-26.

Geddes, Barbara, Joseph, Wright, and Erica Frantz. 2018. How Dictatorships Work. Power Personalization and Collapse. Cambridge, UK: Cambridge University Press.

Gerschewski, Johannes. 2013. "The Three Pillars of Stability: Legitimation, Repression, and Co-Optation in Autocratic Regimes.” Democratization 20:13-38. 
Gerschewski, Johannes. 2019 (forthcoming). “Governing Markets in Autocratic Regimes." In The Governor's Dilemma, edited by Kenneth Abbott, Philipp Genschel, Duncan Snidal and Bernhard Zangl. Oxford: Oxford University Press.

Gilpin, Robert. 1981. War and Change in World Politics. Cambridge: Cambridge University Press.

Hale, Henry. 2015. Patronal Politics. Eurasian Regime Dynamics in Comparative Perspective. New York: Cambridge University Press.

Helfer, Laurence R. 2009. "Regime Shifting in the International Intellectual Property System." Perspectives on Politics 7:39-44.

Hopewell, Kirsten. 2015. "Different Paths to Power: The Rise of Brazil, India and China at the World Trade Organization." Review of International Political Economy 22:311-38.

Ikenberry, G. John. 2009. "Liberal Internationalism 3.0: America and the Dilemmas of Liberal World Order." Perspectives on Politics 7:71-87.

Ikenberry, G. John. 2011a. "The Future of the Liberal World Order." Foreign Affairs 90:56-68.

Ikenberry, G. John. 2011b. Liberal Leviathan. The Origins, Crisis, and Transformation of the American World Order. Princeton, NJ: Princeton University.

Ikenberry, G. John, and Thomas Wright. 2008. Rising Powers and Global Institutions. Washington, DC: The Century Foundation.

Johnson, Tana. 2016. "Cooperation, Co-Optation, Competition, Conflict. International Bureaucracies and Non-Governmental Organizations in an Interdependent World." Review of International Political Economy 23:737-67.

Jupille, Joseph, Walter Mattli, and Duncan Snidal. 2013. Institutional Choice and Global Commerce. Cambridge: Cambridge University Press.

Kahler, Miles. 2013. "Rising Powers and Global Governance: Negotiating Change in a Resilient Status Quo." International Affairs 89:711-29.

Keohane, Robert O. 1989. "Neoliberal Institutionalism: A Perspective on World Politics." In International Institutions and State Power: Essays in International Relations Theory, edited by Robert O. Keohane, 1-20. Boulder, CO: Westview Press.

Keukeleire, Stephan, and Bas Hooijmaaijers. 2014. “The BRICS and Other Emerging Power Alliances and Multilateral Organizations in the Asia-Pacific and the Global South. Challenges for the European Union and Its View on Multilateralism." Journal of Common Market Studies 52:582-99.

Kirshner, Jonathan. 2012. "The Tragedy of Offensive Realism: Classical Realism and the Rise of China." European Journal of International Relations 18:53-75.

Kirton, John J. 2013. G20. Governance for a Globalized World. London: Routledge.

Knaack, Peter. 2017. "An Unlikely Champion of Global Finance: Why is China Exceeding International Banking Standards?" Journal of Current Chinese Affairs 46:41-79.

Krasner, Stephen D. 1983. "Structural Causes and Regime Consequences: Regimes as Intervening Variables." In International Regimes, edited by Stephen D. Krasner, 1-21. Ithaca, NY: Cornell University Press.

Lake, David A. 2009. Hierarchy in International Relations. Ithaca, NY: Cornell University Press.

Lake, David A. 2016. The Statebuilder's Dilemma. On the Limits of Foreign Intervention. Ithaca: Cornell University Press.

Layne, Christopher. 1993. "The Unipolar Illusion: Why New Great Powers Will Rise." International Security 17:5-51.

Lazar, Sian. 2017. "Introduction." In Where are the Unions? Workers and Social Movements in Latin America, the Middle East and Europe, edited by Sian Lazar, 1-16. London: Zed Books.

Lehmbruch, Gerhard. 1984. "Concertation and the Structure of Corporatist Networks." In Order and Conflict in Contemporary Capitalism, edited by John Goldthorp, 60-80. Oxford: Clarendon Press.

Lehmbruch, G. 1987. "Administrative Interessenvertretung." In Verwaltung und Ihre Umwelt, edited by Adrienne Windhoff-Héritier, 11-43. Opladen: Westdeutscher Verlag.

Lipscy, Philip Y. 2017. Renegotiating the World Order. Institutional Change in International Relations. Cambridge: Cambridge University Press.

Mahoney, James, and Kathleen Thelen. 2010. "A Theory of Gradual Institutional Change." In Explaining Institutional Change. Ambiguity, Agency, and Power, edited by James Mahoney and Kathleen Thelen, 1-37. New York: Cambridge University Press. 
Mistry, Dinshaw. 2014. The US-India Nuclear Agreement. Diplomacy and Domestic Politics. Delhi: Cambridge University Press.

Modelski, George. 1987. Long Cycles in World Politics. Seattle, WA: University of Washington Press.

Modelski, George. 2005. "Long-term Trends in World Politics." Journal of World-Systems Research 11:195-206.

Morse, Julia C., and Robert O. Keohane. 2014. "Contested Multilateralism." Review of International Organizations 9:385-412.

Newman, Edward, and Benjamin Zala. 2018. "Rising Powers and Order Contestation: Disaggregating the Normative From the Representational." Third World Quarterly 39:871-88.

Nordland, Rod. 2018. "U.S. Exit Seen as an Abandonment of the Kurds, and a Boon for ISIS." New York Times December 20, 2018: A9.

Olson, Mancur. 1965. The Logic of Collective Action. Public Goods and the Theory of Groups. Cambridge, MA: Harvard University Press.

Organski, Abramo F. K. 1968. World Politics. New York: Knopf.

Organski, Abramo F. K., and Jacek Kugler. 1980. The War Ledger. Chicago, IL: University of Chicago Press.

Paul, Thazha Varkey 2016. "The Accommodation of Rising Powers in World Politics." In Accommodating Rising Powers. Past, Present, and Future, edited by T. V. Paul, 3-32. Cambridge: Cambridge University Press.

Paul, Thazha Varkey, and Mahesh Shankar. 2011. "Why the US-India Nuclear Accord Is A Good Deal." Survival 49:111-22.

Perkovich, George. 2010. "Global Implications of the US-India Deal.” Daedalus 139:20-31.

Pettai, Vello, and Klara Hallik. 2002. "Understanding Processes of Ethnic Control." Nations and Nationalism 8:505-29.

Pierson, Paul. 2000. "Increasing Returns, Path Dependence, and the Study of Politics." American Political Science Review 94:251-67.

Putnam, Robert D. 1988. "Diplomacy and Domestic Politics: The Logic of Two-Level Games." International Organization 42:427-60.

Ren, Xiao. 2015. "A Reform-Minded Status Quo Power? China, the G20, and Reform of the International Financial System." Third World Quarterly 36:2023-43.

Reuter, John, and Graeme Robertson. 2015. "Legislators, Cooptation and Social Protest in Contemporary Authoritarian Regimes." Journal of Politics 77:235-48.

Salehyan, Idean. 2019 (forthcoming). "Militias and the Iraqi State: Shifting Modes of Indirect Governance." In The Governor's Dilemma, edited by Kenneth Abbott, Philipp Genschel, Duncan Snidal and Bernhard Zangl. Oxford: Oxford University Press.

Scharpf, Fritz W. 1978. "Organisatorische Voraussetzungen der Funktionsfähigkeit der Gewerkschaften in der Bundesrepublik Deutschland." Gewerkschaftliche Monatshefte 29:578-88.

Schirm, Stefan A. 2010. "Leaders in Need of Followers. Emerging Powers in Global Governance." European Journal of International Relations 16:197-221.

Schmitter, Philippe C. 1985. "Neo-corporatism and the State." In The Political Economy of Corporatism, edited by Wyn Grant, 32-62. New York: St. Mary's Press.

Schweller, Randall L. 1994. "Bandwagoning for Profit. Bringing the Revisionist State Back in." International Security 19:72-107.

Schweller, Randall L., and Xiaoyu Pu. 2011. "After Unipolarity: China’s Vision of International Order in an Era of U.S. Decline.” International Security 36:41-72.

Selznick, Philip. 1964. TVA and the Grass Roots. A Study in Politics and Organization. Berkeley, CA: University of California Press.

Shleifer, Andrei, and Daniel Treisman. 2005. “A Normal Country: Russia after Communism.” Journal of Economic Perspectives 19:151-174.

Srivastava, Anupam, and Seema Gahlaut. 2012. "India and the NPT. Separating Substantive Facts From Normative Fiction." In The Nuclear Non-Proliferation Treaty and India, edited by Rajiv Nayan, 99111. London: Routledge.

Stephen, Matthew D. 2012. "Rising Regional Powers and International Institutions. The Foreign Policy Orientations of India, Brazil and South Africa." Global Society 26:289-309.

Tamm, Henning. 2019 (forthcoming). “The Invader's Dilemma: Enlisting Rebel Groups.” In The Governor's Dilemma, edited by Kenneth Abbott, Philipp Genschel, Duncan Snidal and Bernhard Zangl. Oxford: Oxford University Press. 
Thomas, Troy S., Stephen D. Kiser, and William D. Casebeer. 2005. Warlords Rising. Confronting Violent Non-State Actors. Lanham, MD: Lexington Books.

Toma, Danny. 2018. America First. Understanding the Trump Doctrine. Washington, DC: Regnery Publishing.

Trotha, Trutz von. 1994. Koloniale Herrschaft. Tübingen: J.C.B. Mohr.

Tsebelis, George. 2002. Veto Players. How Political Institutions Work. Princeton, NJ: Princeton University Press.

Varadarajan, Siddharth. 2008. "NSG Critics Focus on Non-proliferation Benchmarks." Available at http:// www.thehindu.com/todays-paper/NSG-critics-focus-on-non-proliferation-benchmarks/article15287280. ece. Accessed March 20, 2017.

Viola, Lora. 2018. "US Strategies of Institutional Adaptation in the Face of Hegemonic Decline." Paper Prepared for the "Power Shifts and Institutional Change" Workshop, Munich, 5-6 November 2018.

Wade, Robert H. 2011. "Emerging World Order? From Multipolarity to Multilateralism in the G20, the World Bank and the IMF." Politics and Society 39:347-78.

Ward, Steven. 2017. Status and the Challenges of Rising Powers. Cambridge: Cambridge University Press. Weiss, Leonard. 2010. "India and the NPT." Strategic Analysis 34:255-71.

Wilson, Peter H. 2016. The Holy Roman Empire. A Thousand Years of Europe's History. London: Allen Lane.

Wintrobe, Ronald 1998. The Political Economy of Dictatorship. New York: Cambridge University Press.

Zangl, Bernhard, Frederick Heußner, Andreas Kruck, and Xenia Lanzendörfer. 2016. "Imperfect Adaptation. How the WTO and the IMF Adjust to Shifting Power Distributions Among Their Members." The Review of International Organizations 11:171-96.

Zürn, Michael. 2018. A Theory of Global Governance: Authority, Legitimacy, and Contestation. Oxford: Oxford University Press.

Cite this article: Kruck, A., Zangl, B. 2019. "Trading privileges for support: the strategic co-optation of emerging powers into international institutions." International Theory 11, 318-343, doi:10.1017/ S1752971919000101 